$11^{\text {th }}$ ICEEPSY 2020

The International Conference on Education \& Educational Psychology

\title{
MUSICAL AND LINGUISTIC PERCEPTION OF THE FIRST TO THIRD YEAR SCHOOLCHILDREN
}

\author{
Iva Košek Bartošová (a)*, Yveta Pohnětalová (a) Petra Němcová (a), Kateřina Rejfová (a) \\ *Corresponding author \\ (a) University of Hradec Králové, Faculty of Education, Rokitanského 62, Hradec Králové, 500 03, Czech Republic, \\ iva.kosekbartosova@uhk.cz
}

\begin{abstract}
This paper examines the music and language perception capacities of the first to third year primary school pupils. The method used relies on the statistical analysis of hearing tests taken by the children. The goal of the research was to conduct a survey of the children's language memory level and figure out whether any connection exists between the language memory and the children's attitude to music. The language hearing tests constituted the principal research tool. They were adjusted after the accomplishment of the preliminary research, and their results were recorded to the record sheet by the participants themselves. For the data analysis, the Spearman's rank correlation coefficient was used together with the MannWhitney test, the T-test and a questionnaire surveying the level of respondent's affinity to music and foreign languages. The results show that children with a music education scored higher in the hearing tests. The results indicate certain connection between music and language, defined by similar rules on the theoretical basis. Although the results are not statistically significant, they can be used for designing the language teaching methods. We have aimed to provide a deeper insight into the process of learning foreign languages and open the door for further research on the topic.
\end{abstract}

2672-8141 (C) 2020 Published by European Publisher.

Keywords: Memory, music, teaching foreign languages. 


\section{Introduction}

Music and language are both structured according to strict rules which shows certain similarities. Music is an organized system working with tone, melody, sound, harmony, and rhythm (Spitzer, 2014). Language can be defined as a socially shared code, a sum of rules, based on which the speech is generated as the external manifestation of language (Lachout, 2012). The opinion that the speech is processed in the left and language in the right brain hemisphere, e.g. they are processed separately, has been prevalent until the 1970s (Besedová, 2017). Recent research shows there occur multiple interaction between both hemispheres.

According to Besedová (2017), human brain is processing the language the same way as the music, e.g. melody in the right hemisphere and the rhythm of the language in the left one. Another point of contact between language and music is the memory - an irreplaceably important element of any language or music learning process. Anybody who wants to learn playing a musical instrument must employ own memory. The same applies to learning a foreign language - to store and restore information of a previous experience. In learning, certain neural synapses are being established. This implies that the earlier one starts learning music and foreign languages, the more synapses are established in their brain.

In our survey we have attempted to figure out the level of language memory of the first to third year elementary school children, and a potential relation between their language memory and music education. The result of our preliminary research show that the children's affinity to music increase their score in language hearing tests. This could imply the applicability of music education elements for teaching foreign languages.

\section{Problem Statement}

Between the $6^{\text {th }}$ and $11^{\text {th }}$ year of age the language skills develop towards greater complexity, specifically with respect to semantic and syntactic capacities. The semantic capacities are responsible for understanding the meaning of words, the similarity and difference between them. Children learn to recognize different word classes and the ways of their use. The syntactic capacities allow to correctly use grammar rules, which affects the speaking ability and is further dependent on the intelligence and level of thinking.

The American psychologist Gardner (1999) is best known for his multiple intelligence theory. One of them is the music intelligence - the capacity to create, perceive and interpret music. Linguistic or language intelligence then represent the capacity to learn to use and understand languages in both spoken and written form. This intelligence has a crucial impact on the ability to learn foreign languages. With respect to the multiplicity of influencing aspects, the topic of learning foreign languages requires an interdisciplinary approach and a cooperation of experts from the fields of neurology, psychology, pedagogic sciences and linguistic (Besedová, 2017, 2019).

\section{Research Questions}

The main survey was preceded by a preliminary one, providing the insight into the possibilities of examining the problematics. During the preparation phase of the preliminary survey it was necessary to 
adjust the method to the age of the children. The original research was conducted at the Faculty of Education at University of Hradec Králové, which focused on the children 12 years old and older used 30 seconds long speech sequences in individual languages. Ten samples of spoken language were further used, from which sequences containing five different languages were selected. The respondents' task was to recognize specific foreign language.

The texts were easy ones (recorded by native speakers only), the preliminary survey aimed at the children from $1^{\text {st }}$ to $3^{\text {rd }}$ year of the elementary school nonetheless required the shortening of the sequences to 10 seconds. The $1^{\text {st }}$ and $2^{\text {nd }}$ year children were first listening to 6 samples of different languages, always being told what language they are listening to. Subsequently, three samples were selected, and the respondents' task was to recognize the languages. The $3^{\text {rd }}$ year children were first listening to 8 samples and attempted to recognize languages from 4 samples. Furthermore, the questionnaire needed to be shortened of the question for the knowledge of and affection to 9 different languages. The $1^{\text {st }}$ and $2^{\text {nd }}$ year school children only seldom had the opportunity to encounter most of the presented languages. For the $3^{\text {rd }}$ year children this question was kept included. For the $1^{\text {st }}$ and $2^{\text {nd }}$ year primary school children the exact verbal interpretation of the questionnaire was necessary, which increased the time demands of the survey.

For the survey we formulated following research questions:

- What attitude to music do the children from $1^{\text {st }}-3^{\text {rd }}$ year of primary school have?

- How do the respondents perceive foreign language and how they develop their language memory?

- Can any correlation be observed between the children's affinity to music and their language memory?

- Is there any correlation between the respondents' music education of language memory?

\section{Purpose of the Study}

The goal of the study was to conduct a survey of language memory level and attitude of the music among the children from the $1^{\text {st }}-3^{\text {rd }}$ year of primary school. The study aimed to figure out whether there is any correlation between the children's attitude to music and their language memory, respectively between their music education and language memory.

\section{Research Methods}

Just like in the preliminary survey, language hearing tests constituted the principal research tool. Those consisted of 8 (for the $3^{\text {rd }}$ year schoolchildren), or 6 (for the $1^{\text {st }}$ and $2^{\text {nd }}$ year children) sequences of spoken language. The languages selected were the following: Turkish, Russian, Swedish, Spanish, Slovenian, Vietnamese, Chinese, Finnish). The results were recorded to the record sheet by the participants themselves. For the data analysis, the Spearman's rank correlation coefficient was used together with the Mann-Whitney test and the T-test. 
The sample consisted of schoolchildren from the $1^{\text {st }}-3^{\text {rd }}$ year of the primary schools Habrmanova and Bezrušova in Hradec Králové. The sample size was 98 respondents (11 children from $1^{\text {st }}$ year, 29 from $2^{\text {nd }}, 58$ from $3^{\text {rd }}$ ). The gender ratio was 47 girls $/ 51$ boys.

\section{Findings}

The preliminary survey conducted on 23 children from the Mandysova elementary school in Hradec Králové revealed majority of children between 6 and 9 years of age to have a positive affinity to both music and learning a foreign language. Their score in the language memory test (samples of different spoken languages) has been confirmed $(16 \%)$. We aimed to verify or falsify, that the $1^{\text {st }}$ and $2^{\text {nd }}$ year schoolchildren only guess the language during the test, as suggested by the preliminary survey. The correlation coefficient between the affinity of music and language test score $(0.580552)$ is interesting to us as well, as it may inspire our future research.

In this paper, we only focus on the research question and most relevant data.]

\subsection{Affinity to music among 1. - 3. year primary school pupils}

Both the preliminary and main survey (Figure 01 ) revealed majority of respondents $(n=67)$ having a positive affinity to music (i.d. $68.4 \%$ ). Only one respondent had no positive affinity ( $\mathrm{n}=67$ ) has a very positive affinity to music (i.d. 68.4\%). Only one respondent has no positive affinity to music.

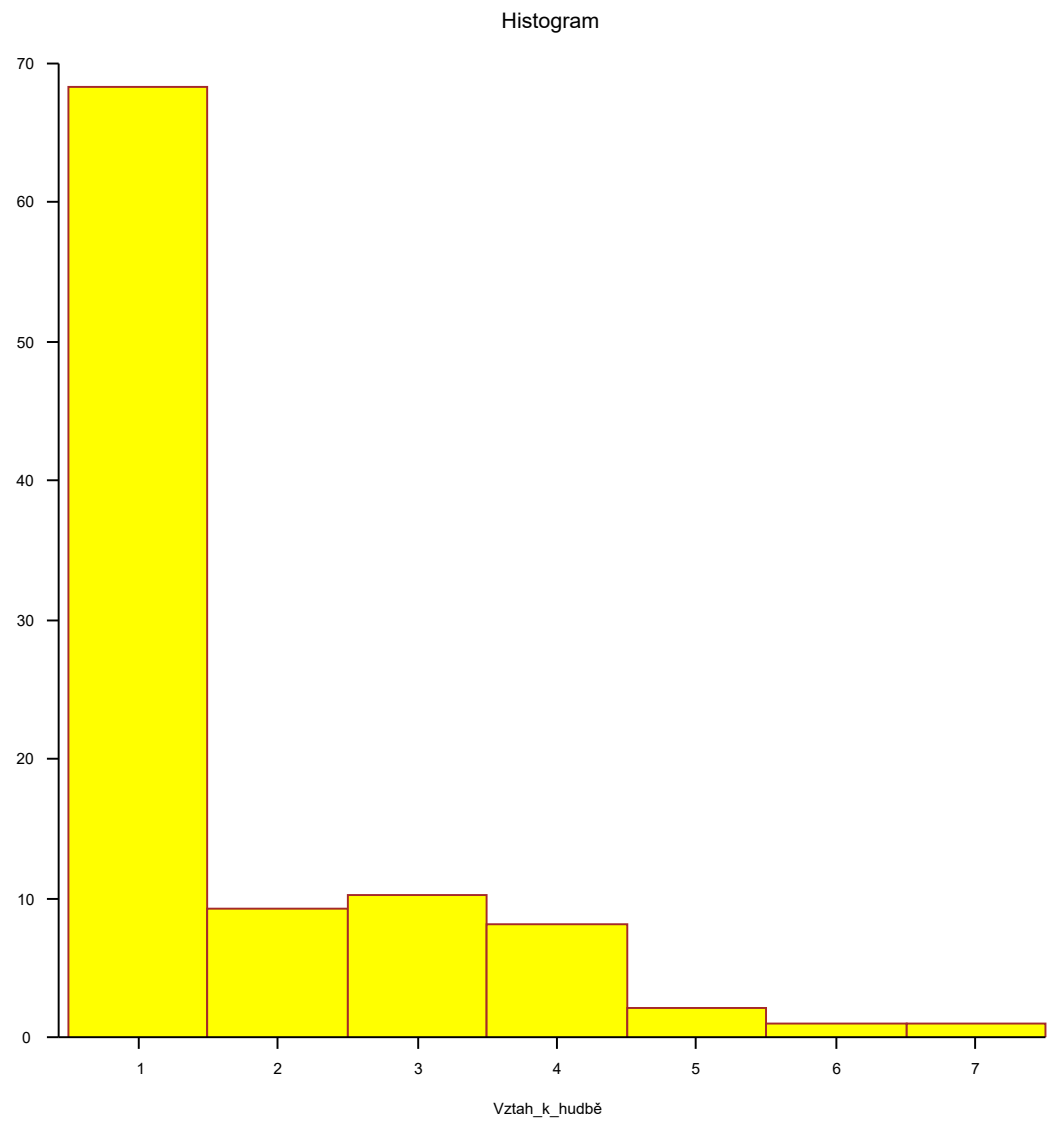

Figure 01. Affinity to music 
In the main survey, $69.6 \%$ of children have shown a very positive affinity to music, which corresponds to the preliminary survey results.

Here too the results show melody was playing a pivotal role for respondents $(n=35 ; 35.7 \%)$ in the respondents' perception of music sung in their native language. Only for 7 respondents, the text of the song was essential. A significant number (37) showed shared focus on both melody and text. The absolute majority $(n=64 ; 65.3 \%)$ of respondents was attracted to a song with a likeable melody sung in a language unknown to them.

\subsection{Perception of a foreign language and the language memory}

Before the children took the language memory listening test, we aimed to figure out the affinity of the respondents to individual languages (Table 01). The children were asked to express their affinity to the languages on the $100 \%-0 \%$ axis $(100 \%=$ maximal affinity; $0 \%=$ zero affinity or never heard the language). With respect to the questionnaire modification, this question was relevant for the $3^{\text {rd }}$ year schoolchildren only.

Table 01. Foreign language perception

\begin{tabular}{|l|l|l|l|l|l|l|l|}
\hline & Average & Standard deviation & Min. & Max. & Range & Median & Modus \\
\hline English & 0,68 & 0,27 & 0,2 & 1 & 0,8 & 0,7 & 1 \\
\hline Russian & 0,19 & 0,37 & 0 & 1 & 1 & 0 & 0 \\
\hline French & 0,10 & 0,24 & 0 & 1 & 1 & 0 & 0 \\
\hline Spanish & 0,13 & 0,28 & 0 & 1 & 1 & 0 & 0 \\
\hline German & 0,21 & 0,33 & 0 & 1 & 1 & 0 & 0 \\
\hline Slovak & 0,58 & 0,39 & 0 & 1 & 1 & 0,6 & 1 \\
\hline Italian & 0,18 & 0,35 & 0 & 1 & 1 & 0 & 0 \\
\hline Chinese & 0,08 & 0,22 & 0 & 1 & 1 & 0 & 0 \\
\hline Vietnamese & 0,04 & 0,11 & 0 & 0,5 & 0,5 & 0 & 0 \\
\hline
\end{tabular}

The results have met our assumption. The children have the highest affinity to English, which they also know the best (68\% affinity), as English language is usually being taught since the 1st primary school year. The Slovak language, similar to Czech language, scored second (58\%).

The language memory testing has been crucial for our research. Just like in the preliminary survey, the 3 rd year children were asked to identify 4 language samples out of 8 (see the methodology), the 1 st and 2 nd year children should identify 3 samples out of 6 . Each sample has been approximately $10 \mathrm{sec}$ long (see Table 02).

Table 02. Language memory score

\begin{tabular}{|l|l|l|l|l|l|l|l|}
\hline Score & Average & Standard deviation & Min & Max & Range & Median & Modus \\
\hline Score & 0,23 & 0,2 & 0 & 0,8 & 0,8 & 0,2 & 0,2 \\
\hline
\end{tabular}

The score of this listening test is higher than in the preliminary survey $-23 \%$ of respondents compared to $16 \%$ in the preliminary. Here the standard deviation is wide as well. The score most typical was about $20 \%$. The identification of the language has been once again proved very difficult to the $1^{\text {st }}$ and $2^{\text {nd }}$ year children, who were often just guessing the language. Some of the languages they heard for the very first time, becoming rather distracted by the listening. 


\subsection{Correlation between the affinity to music (music education) and the language memory}

The relation between the score in the language hearing test and the affinity to music had been indicated by the preliminary survey (Spearman coefficient 0.580522 . In the main survey however, these results were not confirmed (Spearman coefficient 0.121739). This was a surprising result to us. We will now proceed to the survey conducted on the $4^{\text {th }}$ and $5^{\text {th }}$ year schoolchildren.

We considered it proper to test the correlation between the formal music education (learning a music instrument of theory) and the language memory. We were nonetheless expecting no difference in score between the children receiving such education and the control group, given the fact the children were receiving the music education for a short period of time ( $1-3$ years).

For this testing we used the Student T-test. Given the character of the data (their normality has not been fully confirmed), the Mann-Whitney non-parametric test was used for testing the median values. The T-test results $(p=0.01700 ; t=2.4291)$ and the Mann-Whitney test results $(p=0.014699 ; Z=-2.4397)$ indicate the children with formal music education score higher in the test. Our supposition has therefore been not confirmed. The survey conducted on the $4^{\text {th }}$ and $5^{\text {th }}$ year schoolchildren will likely provide further valuable evidence.

\section{Conclusion}

The research has brought some interesting results. Their impact is however limited, as, the respondents had just minimal experience with both foreign language and music education. That is why we will intent to focus on a sample of children between 9and 11 years of age. Here we will test if the music education is a factor for higher score in the language hearing tests.

\section{Acknowledgments}

The article was created on the basis of the Specific Research of Faculty of Education of University Hradec Králové No 2105. The study has been approved by the ethics committee of Faculty of Pedagogical sciences, University of Hradec Králové, on 22nd January 2019.

\section{References}

Besedová, P. (2017). Hudba ve výuce cizích jazyků.[Music in teaching of foreign languages]. Grada, p. 163.

Besedová, P. (2019). Correlation of memorial learning in foreign languages and music. Comparative study of elementary school pupils in the Czech Republic. The European Proceedings of Social and Behavioural Sciences EpSBS, 72, 289-298.

Gardner, H. (1999). Dimenze myšlení: teorie rozmanitých inteligencí [Dimension of thinking: theory of multiple intelligence]. Portál.

Lachout, M. (2012). Kde bydlí řeč. Jazyk a myšlení - osvojování, modely a praxe. [Where the speech lives. Language and thinking - acquisition, models and practice]. Metropolitan University Prague Press.

Spitzer, M. (2014). Musik im Kopf. Hören,Musizieren, Verstehen und Erleben im neuronalen Netzwerk [Music in the head. Listening, making music, understanding and experiencing in the neural network]. Schattauer. 